\title{
THE SUBURBAN LAND QUESTION
}

\section{A Global Survey}

Edited by Richard Harris and Ute Lehrer

When discussing the suburbs and the process of suburbanization namely, the conversion of rural land to urban use - most writers focus on particular countries in the northern hemisphere, implying that patterns and processes elsewhere are fundamentally different. The purpose of The Suburban Land Question is to identify the common elements of global suburban development, focusing on issues associated with the scale and pace of rapid urbanization around the world.

The contributors to the volume draw on a variety of sources, including official data, planning documents, newspapers, interviews, photographs, and field observations, to explore the patterns, processes, and planning of suburban land development. Featuring case studies from China, India, Latin America, South Africa, as well as France, Austria, the Netherlands, the United States, and Canada, this volume discusses the peculiarly transitional character of suburban land and addresses the many elements that distinguish land development in urban fringe areas, including economy, social infrastructure, and legality.

(Global Suburbanisms)

RICHARD HARRIS is a professor in the School of Geography and Earth Sciences at McMaster University.

UTE LEHRER is an associate professor in the Faculty of Environmental Studies at York University. 


\section{GLOBAL SUBURBANISMS}

Series Editor: Roger Keil, York University

Urbanization is at the core of the global economy today. Yet, crucially, suburbanization now dominates 21 st-century urban development. This book series is the first to systematically take stock of worldwide developments in suburbanization and suburbanisms today. Drawing on methodological and analytical approaches from political economy, urban political ecology, and social and cultural geography, the series seeks to situate the complex processes of suburbanization as they pose challenges to policymakers, planners, and academics alike.

For a list of the books published in this series see page 341. 


\section{EDITED BY RICHARD HARRIS AND UTE LEHRER}

\section{The Suburban Land Question}

A Global Survey 
(C) University of Toronto Press 2018

Toronto Buffalo London

www.utorontopress.com

Printed in the U.S.A.

ISBN 978-1-4426-4959-0 (cloth) ISBN 978-1-4426-2695-9 (paper)

(2) Printed on acid-free, $100 \%$ post-consumer recycled paper with vegetablebased inks.

(Global Suburbanisms)

\section{Library and Archives Canada Cataloguing in Publication}

The suburban land question : a global survey / edited by Richard Harris and Ute Lehrer.

(Global suburbanisms)

Includes bibliographical references and index.

ISBN 978-1-4426-4959-0 (cloth). - ISBN 978-1-4426-2695-9 (paper)

1. Suburbs - Case studies. 2. Cities and towns - Growth - Case studies.

3. City planning-Case studies. 4. Land subdivision-Case studies.

I. Harris, Richard, 1952-, editor II. Lehrer, Ute, 1960-, editor III. Series:

Global suburbanisms

HT351.S96 $2018 \quad 307.74 \quad$ C2017-908045-8

Collage on chapter opening pages johnwoodcock/iStockphoto and Alhontess/iStockphoto

University of Toronto Press acknowledges the financial assistance to its publishing program of the Canada Council for the Arts and the Ontario Arts Council, an agency of the Government of Ontario.

Canada Council for the Arts

Funded by the

Government of Canada
Financé par le gouvernement du Canada
Conseil des Arts du Canada 